\title{
POLLUTION AND BIOLOGICAL INVASION OF COASTAL ENVIRONMENT THROUGH BALLAST WATER OF SHIPS
}

\author{
B.V. Seshagiri Rao ${ }^{1}$ and K. Varahala Raju ${ }^{2}$ \\ ' Formerly, Reader and Head, 24-6-3(A), Sindhuri, Dasika Vari Street, Srirampuram, Bhimavaram, Andhra Pradesh 534202, India \\ ${ }^{2}$ Reader, Department of Zoology, D.N.R. College (Autonomous), Bhimavaram, Andhra Pradesh 534202, India
}

Po!lution and biological invasion of coastal environment through ballast water of ships has become a global problem. Fisheries, coastal aquaculture and human health are affected directly or indirectly through contaminated water and animals introduced through ballast water. While a number of maritime states are seriously thinking about the problem of ballast water management, awareness seems to be lacking in our country. Details about the animals, bacteria and other pathogens introduced into coastal waters of one country from another country are discussed.

Contamination of ships ballast water by unwanted aquatic organisms and pathogens is one of the reasons for pollution and biological invasion of coastal zone of several countries all over the globe. The problem occurs because cargo ships have to take on sea water into their ballasts on certain voyages. Bulk carriers and tankers sometimes carry the cargo one way only. During the return journey, after unloading the cargo, some weight must be added so that the propeller of the ship is properly immersed and other seagoing properties like stability and strength of the hull are not disturbed (Anon, 1993). This practice of pumping in water into ballast tanks is in vogue since the late 1870 s. Usually the ballast water is taken outside the port and is discharged on approaching the loading port. In this way, the ballast water is carried thousands of miles from the coastal region of one country to another country. This water is suspected to introduce infectuous diseases through water borne organisms, viruses or bacteria that may cause severe harm to fisheries, aquaculture production, public health and coastal environment.

According to a report (GESAMP, 1997) in the Black Sea region there was a population explosion of the comb jelly, a predatory ctenophore, Mnemiopsis leidyi. These comb jellies reduced the zooplankton by feeding on it which is the food for fish larvae. Also, they started feeding on the fish eggs and larvae. This comb jelly is suspected to have been introduced through the ballast water of ships. Because of heavy fishing, the predatory fish and small pelagic fish populations declined leading to large

Rceived on 29 October 1999

Accepted on 13 January 2000 scale increase in zooplankton and when the comb jellies were introduced they found abundant food material at their disposal resulting in population explosion that severely affected the fisheries.

It is believed that the diatom Biddulphia sinensis and the mitten crab Eriochoir sinensis found on the German coast were both introduced from China (Anon, 1994). Presently the German Federal Environment Agency is carrying out a survey of ballast water in ships visiting German ports. About thirty five species of organisms consisting of barnacles, shellfish and others have been recorded from ballast water samples.

A sample survey of ballast water carried on foreign ships conducted in Canada indicated the presence of over 150 distinct species of phytoplankton and 56 species of invertebrates. This study conducted during 1980 has shown that organisms are capable of surviving in ballast water upto 18 days (Anon, 1989). In U.S.A. cholera vibrio has been detected in ballast water of ships from South America.

About 60 million tonnes of ballast water is discharged into Australian waters annually (Anon, 1990). Research has established that toxic dinoflagellates like Gymnodium catenatum and Alexandrium tanarense have been introduced into Australian waters and have established themselves. These dinoflagellates were first observed in 1980 and were not present in earlier plankton samples. The protozoan Gymnodium is known to be present in the waters of Argentina, Japan, Mexico, Portugal, Spain, Venezuela and several other areas of the Mediterranean ports. These toxic dinoflagellates present a threat to Australia's shellfish farming industries on the coastline especially Tasmania. The infected shellfish can cause paralytic shellfish poisoning in humans leading to mortality and many such deaths were recorded. Other suspected introductions into Australia are the Japanese kelp, Japanese shrimp, a shore crab, a goby and several mussels. It is reported that atleast 14 foreign organisms have been introduced into Australian waters through ballast water discharge. It is possible that viral and bacterial disease carrying organisms are also introduced that will endanger coastal 
aquaculture. The Japanese kelp Undria pinnatifida has spread to the east coast of Tasmania with disastrous effect on the abalone industry, oyster and mussel farms. The Japanese starfish Asterias amurensis is spreading to southern Tasmania having impact on shellfish industries.

So far, investigations carried out in several countries have established that microorganisms, some invertebrates and aquatic plants are carried from one place and introduced at another place due to ballasting and deballasting by ships. There is reason to suspect that even higher organisms like fish are introduced by ballast water. Fish eggs and larvae, if introduced into favourable environment can develop and establish themselves firmly often replacing similar but weaker species. In India, the suspected migration or presence of an Atlantic and Mediterranian species of sardine Sardinella aurita on the West Coast (Dutt et al., 1983) and Australian threadfin, Polynemus sheridani on the east coast (Girijakumar et al., 1984), the occurrence of oil sardine, Sardinella longiceps north of Madras on the east coast from where it was not recorded earlier may also be due to ballast water discharges.

A questionnaire was circulated to 5 important ports in India by the authors regarding information on ballast water. A reply was received from one major port only. It is presumed that the concerned authorities in our country are not aware of the implications of ballasting and deballasting. The International Maritime Organization (IMO) has formulated guidelines for preventing the introduction of unwanted aquatic organisms and pathogens from Ship's ballast water and sediment discharge. The potential for ballast water discharges to cause harm was recognised by Resolution 18 of International Conference on Marine Pollution, 1973. This resolution also called upon the World Health Organisation to carry out research into the role of ballast water, as a medium for the spreading of epidemic disease causing bacteria. Australia has submitted a report based on an International survey of IMO member states relating to ship's ballast water to the 34th session of Marine Environment Protection Committee during July, 1993.

Following the guidelines from IMO some countries like Australia, Japan and Canada are developing specific testing programmes of ballast water for toxic dinoflagellates, cholera vibrio and other harmful bacteria. In view of the importance of ballast water impact on coastal environment in general, fisheries, aquaculture and human health in particular, there is an immediate need to investigate the problem and formulate suitable strategy for ballast water management in India.

\section{References}

Anon (1989). IMO News No. 2. The Magazine of the International Maritime Organization, London.

Anon (1990). IMO News No. 2. The Magazine of the International Maritime Organization, London.

Anon (1993). IMO News No. 3. The Magazine of the International Maritime Organization, London.

Anon (1994). IMO News No. 2. The Magazine of the International Maritime Organization, London.

Dutt, S. and K. Varahala Rajn (1983). A new record of Sardinella aurita Valenciennes, 1847 (Teleostei: Clupeidae) from the eastern part of the Arabian Sea: A possible immigration through the Red Sea. Bull Institute of Oceanography and Fisheries. Egypt. 9: 264-270.

GESAMP (1997). (IMO/FAO/UNESCO-ICO/WHO/IAEA/UN/ UNEP Joint Group of Experts on the scientific aspects of Marine Environmental Protection). Opportunistic settlers and the problem of the ctenophore Mnemiopsis leidyi invasion in the Black Sea. Rep. Stud. GESAMP, London, (58): 83p.

Girijakumari, S.B. Ratnamala and B.V. Seshagiri Rao (1984). A new record of the threadfin Polynemus sheridani Macleay from India. Matsya (9-10): 196-198. 